\title{
Collateral Pledge: Does Relationship Lending Matters? The Case of Maize Farmers in Ghana
}

\author{
Stephen Antwi* Kwasi Ohene-Yankyira \\ Department of Agricultural Economics, Agribusiness and Extension, Faculty of Agriculture, College of Agriculture and Renewable \\ Natural Resources, Kwame Nkrumah University of Science and Technology, Kumasi Ghana \\ *Corresponding author: santwi53@yahoo.com
}

\begin{abstract}
A survey was employed to gather the primary data needed to assess how relationship lending affect the collateral that must be pledged by the maize farmer borrowers when taking credit from financial institutions. The farmers were selected from 8 districts in Ashanti and Brong Ahafo regions of Ghana. Multi-stage purposive and randomized sampling technique was used to sample 380 maize farmers. Descriptive statistics were used to evaluate collateral and socio-economic characteristics of the respondents while logit regression analysis was used to measure the effects of relationship lending on collateral used to secure loans taken by maize farmers. The results revealed farmer's access to information has a reverse and significant with the collateral used to secure loans .multiple banking relationships is significant and directly related to the collateral used by farmers. The previous loan repayment behavior inversely affects the collateral pledge and is significant. Farmers who have investments with the bank are able to argue for lower or no collateral since those investments are used as securities. This explains the negative relationship with the collateral pledge. Thus farmers are encouraged to build more relationship with their banks in the form of investments, good repayments, getting more information minimizing the number of banks they deal with.
\end{abstract}

Keywords: collateral pledge, relationship lending, agricultural credit, information asymmetry, Brong Ahafo and Ashanti Region, Ghana

Cite This Article: Stephen Antwi, and Kwasi Ohene-Yankyira, "Collateral Pledge: Does Relationship Lending Matters? The Case of Maize Farmers in Ghana.” American Journal of Rural Development, vol. 5, no. 2 (2017): 30-38. doi: 10.12691/ajrd-5-2-1.

\section{Introduction}

Financial institutions need information about the business and the borrowing behavior of the borrower in order to assess the profitability of the business and the credit worthiness of the customer before loans are approved and disbursed [63].

However most of the farmers in Ghana do not keep records of their activities because of high rate of illiteracy or lack of desire to do so [48].

The inability of the farmers to provide information about their activities has been seen as the major reason why the banks are not willing to provide credits to the farmers [63]. Thus information asymmetry is a challenge in agricultural credit delivery [6].

That was why [60], said, access to agricultural credit has been severely constrained in developing countries because of the imperfect and costly information problems Lack of information makes the credit process more risky and costly.[6]. To compensate for the increased cost and the riskiness in the lending process, financial institutions may charge higher interest rate thereby making loans expensive [49]. or use other non-price mechanisms to allocate loans [37]. One of such non-price mechanism the demand for more collateral from the farmers before the loan is disbursed. Before the loans are approved and disbursed, the borrowers are made to provide collateral and guarantors to secure the loans [13]. The title to the assets used as collateral is transferred to the lender who now has claim over the specific assets and this prevents the borrower from selling or disposing of the asset. On the other had an item used to guarantee a loan can be sold by the borrower without any limit since the lender is seen to have only a general claim over the item. This is because ownership is not transferred to the financial institution when the item is used as guarantee. But if the item is still there, the lender can get hold of it to defray the interest and the principal when there is default in repayment [44].

The Ghanaian banking system relies heavily on collateral as shown by [57]. More than $90 \%$ of Ghanaian small borrowers are made to either provide collateral or guarantees in addition to guarantors before they are able to in access credit because of high risk of default which needs to be well managed [18].

Collaterals have two different roles according to the literature on bank lending. In the first place it serves to mitigate some of the losses suffered by the bank in case of default (loss at default) [16]. This is also known as provision of hedge against default [64].

The second reason why financial institutions take collaterals is that, collaterals aligns the interest of both the lenders and borrowers together and this helps to solve the challenges caused by moral hazard and adverse selection which is the incidence of loan default [44]. 
The argument is that collaterals increase the interest of the borrowers in the contract and because the they do not want to lose the asset used as collaterals, they are pushed to work harder in order to pay back the loan [5].

That was why [64], opined that collaterals are used to reduce the incidence of loan default since it changes the behaviors of the borrowers.

[56] found that the total value of the assets compared with the amount of loan being applied is an important factor when it comes to the pledging of collateral. Upon the argument in favor of collateral pledge, some researchers have shown that collateralized loans are those with a higher probability of default. [40] According to [39], relationship lending is one of the mechanisms by which information asymmetry in credit delivery can be reduced. Relationship lending is a lending technology in which the financial institution bases its credit decisions in substantial part on proprietary information about the borrower through a variety of contacts over time. Through the establishment of long term relationships between a bank and a client(farmer), soft information is acquired over time and this information helps the bank to determine the character, reliability, and trust of a the farmer when it comes to lending to the farmer [49].

Relationship between borrowers and banks is measured in part through the provision of loans [14], Duration (years) of account operation [52] deposits, investments, other financial products [21] multiple banking relationships [13], and the borrower's ability to get information from the officers of the bank [34].

According to [21], when there is relationships, a bank may reduce or waive its demands for collateral from such a borrower thereby reducing the costs associated with collateral search, verification and valuation which increases transaction cost [4].

The question is how can relationship lending be used as a mechanism to reduce the pledging of collateral in credit delivery in Ghana? It is expected that relationship lending measured by the observable factors such as duration of account operation, prompt loan repayment, deposit or investment level of the farmer and the farmers ability to get information from the bank will have negative effects on the collateral pledged by farmers .However dealing with multiple banks is expected to increase collateral pledged by farmer.

The remainder of the paper is organized as follows. Section 2.1 reviews the Literature on relationship lending while section 2.2 captures the conceptual framework of collateral requirements. Section.3. describe the data and Methodology used in the empirical analysis, while section 4 presents the results and discussion. Conclusion and policy implication of the study appears in Section 5.

\section{Literature Review}

In general before loan are approved and granted to the borrowers, the bank and for that matter the lender normally demand security in the form of collateral or personal guarantees [13]. The financial institutions take the security for some reasons. The banks claim that by taking the collateral, borrowers do everything possible to pay back the loan since they are not willing to lose ownership of their assets. This help to address problems of moral hazard and adverse selection, reducing implicitly the probability of default [64]. Second, the collateral can be disposed of to pay off both the principal and interest in case of default. This reduces the loss of default for the lender [16] and thereby providing the bank with a hedge in case of default [64].

It is important to note that loans that attract collaterals are those with a higher probability of default [40]. According to [12], whether the bank will take collateral or not depends on the characteristics of the farmer taking the loan, the loan size, availability of information, the length of the relationship, the age of the firm and the features of the governance structures covering the loan contract.

As the firm grows in age, scholars point out that the probability of gaining access to credit increases with a decrease in the request for collateral since newer firms are considered to be the risky to be dealt with [3].

[40] explain that younger firms are more prone to provide collateral as a way of signaling that they have no problems of moral hazard. As the firm grows older, the relationship with the bank increases, and this reduces the collateral requirements [23,37].

Indeed, firms with more experience and with a longer relationship provide banks with a greater amount of private information, giving them the possibility to discriminate between firms with poor track records and those that present moral hazard and adverse selection risks [14,24].

Relationship exhibits a matter of closeness [52]. The value of private information depends on its concentration, as the greater the concentration, the more complete the information thus the lower the request for collateral. Finally, relationship lending is a matter of quality of information, if the bank gets quality information from clients as a result of closeness it becomes easy for the bank to evaluate the riskiness of the firm and hence the lower the request for collateral [35].

Research by [42] found a negative correlation between lending relationship and the collateral request from the bank. That is greater interaction is associated with lower collateral demand. [16], also argue that in local and more concentrated markets, lenders have better information about borrowers. Thus, in general lenders ask for less private collateral as the relationship with clients becomes more intense

\section{Research Methodology}

\subsection{Study Area}

The study area consists of two administrative regions in Ghana, Ashanti and Brong Ahafo. The area occupies a total land area of 63,946 square kilometers and is centrally located in the middle belt of the country. The area lies between longitude $0.15 \mathrm{~W}$ and $2.25 \mathrm{~W}$ and latitude 5.50 and 7.46 north of the equator (Figure 1 ). The population of the study area is about 7,091,363.00 representing about $28.75 \%$ of the national population [28]. The annual average rainfall ranges between $1000 \mathrm{~mm}$ and $1400 \mathrm{~mm}$. The rainfall pattern is bimodal; the major rainy season starts in March, with a minor peak in August tapering off in November. 
The study area has a tropical climate with high temperatures averaging $23^{\circ} \mathrm{C}$ [30]. Agriculture and related work is the major occupation in all the districts within the study area, though the level and intensity as well as farming systems vary between districts. The proportion of working population engaged in agriculture and agriculture related activities in Brong Ahafo Region ranges from a low of $65.7 \%$ in Sunyani to a high level of $83.0 \%$ in Sene District. In Ashanti Region it ranges from 45\% in Kumasi Metropolitan area to about 82\% in Adansi West and East Districts [29].

\subsection{Sampling Techniques}

The sample was selected in three (3) stages; first was the purposive selection of regions followed by the purposive selection of districts. Agricultural activities guided the selection of the two regions while the districts were selected based on the level of maize production using official statistics from [48]. After a consideration of the objectives of the study and time and resources available, eight (8) districts were selected including three from Ashanti Region and five from Brong Ahafo Region. In Ashanti Region the districts whose (Ejura Sekyedumase, Asante Akim North Offinso North) maize output in 2012 exceeded 15,000 metric tonnes, were selected. The Five districts (Dormaa, Nkoranza North, Sunyani west, Sunyani west, Techiman Kintampo North) selected in Brong Ahafo Region had a minimum of 30,000 metric tonnes of maize output in 2012 [48]. The third stage of the sampling involved the identification and listing of the communities and the maize farmers in the operational area. This was undertaken with the help of Agricultural Extension Agents (AEAs) in charge of the operational areas in each of the selected districts. A full list of all the maize farmers; both those who had an account with financial institutions and those who did not have accounts were taken from the extension officers. Because the emphasis of this research is on how relationships affect access to credit and credit can only be obtained when the farmer has an account, those who did not have accounts were purposely exempted. From the list of farmers who had an account, a sample was selected through the following process. The name of each farmer was written on a piece of paper and properly folded. The folded papers containing the names were thoroughly mixed in a bowl. The folded paper was then randomly picked one at a time from the bowl until the needed sample size for the district was reached.

To obtain the total number of respondents, the estimation method given by [17] was used. The method is as follows:

$$
n=\frac{S^{2}(x)(y)}{(E)^{2}}
$$

Where $n=$ Sample size, $x=$ the proportion of the population who have access to credit, $y .=$ the proportion of the population who do not have access to credit, $S=$ Number of standard deviation for a chosen confidence interval level, $E=$ The allowable margin of error.

According to GLSS6 report, on an average, $45 \%$ of individuals living in rural areas, at least save with one of the following financial institutions; Commercial banks,
Rural banks, Savings \& loans companies and cooperative credit unions and thus have the possibility of getting access to credit [28]. Thus, assuming 95\% confidence level and 5\% margin of error,

$$
n=\frac{1.96^{2} \times 0.45 \times 0.55}{0.05^{2}}=380 .
$$

Therefore 380 farmers were sampled for the study however 308 applied for loans. Apart from the sampled maize farmers, the study also interviewed representatives of the financial institutions mostly used by the farmers operating within the selected districts to get their views on the role of relationship lending on credit delivery to farmers. The respondents from the financial institutions were made up of Credit officers, Relationship officers and managers who are in charge of credit delivery in the financial institutions. SPSS was used for the data Entry but was transferred to STATA for the analysis to be made

\subsection{Model Specification}

To examine the impact of lending relationships on collateral pledged by maize farmers for the loans applied, logit model was used to examine probability of a loan being secured or not following [23].

The dependent variable, Collateral is a dummy or binary one which assumes the value 1 if the loan is secured with collateral and 0(zero) otherwise.

The explanatory variables were chosen based on the review of the existing literature like and [15,23,52].

Let $Y_{i}$ represent the bank's decision to demand or not to demand collateral from borrowers. $Y_{i}$ is assumed to be dependent on a vector of loan characteristics, institutional factors as well as relational factors $\left(X_{i}\right)$. The relationship between dependent and independent variables is formulated as follows:

$$
Y_{i}=+\beta_{1} \beta_{2} X_{i}+\mu_{i}
$$

Since we only want to know whether the banks demand collateral or not when the relationship between the bank and the client becomes intense, we therefore define another variable $Y^{*}$ such that:

$Y_{1}^{*}=1$ if the farmer secures the loan with collateral when there is relationship lending

$Y_{1}^{*}=0$ if the farmer does not secures the loan with collateral when there is relationship lending.

Hence

$$
Y_{i}^{*}=\beta_{1}+\beta_{2} X_{i}+\mu_{i}, \mathrm{Y}=1\left(Y_{i}^{*}>0\right)
$$

This means $\mathrm{Y}$ is one when $Y_{i}^{*}>0$ and $\mathrm{Y}$ is zero if $Y_{i}^{*} \leq 0$. Linear Probability Model (LPM), probit and logit models can be used to analyze data involving a binary qualitative dependent variable. [32] noted that though Linear Probability Model can be used to analyze binary models such as the one under consideration, the model has serious defect because, the estimated probability values can lie outside the normal $0-1$ range. Hence probit and logit models are advantageous over LPM in that the probabilities are bound between 0 and 1 .

Statistically, there are similarities between logit and probit models, [1] and that either of them can be used in 
estimation of binary choice models such as the one under consideration. But the logit model was chosen over the probit model for the study since it can be written in terms of odds and log odd for easy interpretation of coefficients [35]. Thus It is assumed that $\mu_{i}$ is independent of $X_{i}$ and that $\mu_{i}$ has standard logistic distribution. Also $\mu_{i}$ is symmetrically distributed about zero.

The logistic model can be represented by the standard linear regression model as given in (3.6.2)

$$
Y_{i}^{*}=\beta_{1}+\beta_{2} X+\mu_{i}
$$

Using the logistic function, the probability $\left(\mathrm{p}_{\mathrm{i}}\right)$ that the financial institution will take collateral is given by

$$
\mathrm{p}_{i}=\frac{1}{1+e^{-Y_{i}^{*}}}=\frac{1}{\left.1+e^{-\left(\beta_{1}+\beta_{2} X+\mu_{i}\right.}\right)} .
$$

The equation restricts $\mathrm{p}_{\mathrm{i}}$ to lie between 0 and 1 as required for probability

$$
1-\mathrm{p}_{i}=\frac{\left.e^{-\left(\beta_{1}+\beta_{2} X+\mu_{i}\right.}\right)}{1+e^{-\left(\beta_{1}+\beta_{2} X+\mu_{i}\right)}}
$$

let $\beta_{1}+\beta_{2} X+\mu_{i}=\mathrm{Z}$

Then equation (3) becomes

$$
1-\mathrm{p}_{i}=\frac{e^{-z_{1}}}{1+e^{-z}}
$$

Rearranging

$$
e^{z}=\frac{\mathrm{p}_{i}}{1-\mathrm{p}_{i}}
$$

Taking the log of both sides

$$
\begin{gathered}
\ln e^{Z}=\ln \left[\frac{\mathrm{p}_{i}}{1-\mathrm{p}_{i}}\right] \\
z_{1}=\ln \left[\frac{\mathrm{p}_{i}}{1-\mathrm{p}_{i}}\right] \\
\ln \left[\frac{\mathrm{p}_{i}}{1-\mathrm{p}_{i}}\right]=\beta_{1}+\beta_{2} X_{1}+\mu_{i}
\end{gathered}
$$

The cumulative logistic probability model is econometrically specified as follows:

$$
\mathrm{P}_{\mathrm{i}}=\mathrm{Y}_{\mathrm{i}}^{*}=\mathrm{F}\left(\beta_{1}+\sum \beta_{2} \mathrm{X}_{\mathrm{i}}\right)=\mathrm{F}\left(\mathrm{Z}_{\mathrm{i}}\right)=\frac{1}{1+\mathrm{e}^{-\mathrm{Z}_{\mathrm{i}}}}
$$

Where, $\mathrm{P}_{\mathrm{i}}$ is the probability that a bank will demand collateral or not when there is relationship lending given $X_{i} ; \mathrm{X}_{\mathrm{i}}$ represents the $\mathrm{i}^{\text {th }}$ explanatory variable; and $\beta_{1}$ and $\beta_{2}$ are parameters to be estimated.

The empirical model is specified as:

$$
\begin{aligned}
C O L L= & \alpha+\beta_{1} \text { LSIZE }+\beta_{2} \text { LTERM }+\beta_{3} \text { AGE } \\
& +\beta_{4} \text { PRELOAN }+\beta_{5} \text { COMPETITION } \\
& +\beta_{6} \text { DEPOSIT }+\beta_{7} \text { INVESTMENT } \\
& +\beta_{8} \text { LDURATION }+\beta_{9} \text { MULTYBANKS } \\
& +\beta_{10} \text { LINTEREST }+\beta_{11} \text { EDUC }+\beta_{12} \text { TLOAN } \\
& +\beta_{13} \text { FAINFO }+\beta_{14} \text { OINCOME }+\varepsilon .
\end{aligned}
$$

Where [COLL] the dependent variable, Collateral, is a dummy or binary one which assumes the value 1 if the loan is secured with collateral and 0(zero) otherwise. It denotes whether the farmer pledges collateral or not when the relationship between the bank and the farmer becomes intense. LSIZE represents the size of the loan while LTERM represents the duration or the term of the loan. The age of the farmer is represented by FAGE while competition in the market and the turnover of the borrower are represented by COMPETITION and TURNOVER respectively. PRELOAN represents previous loan repayment. It takes the value 1 if the farmer was able to pay off his loan within a maximum of 30 days when the repayment date falls due and zero otherwise. Good repayment of loans is expected to attract lower collateral while DEPOSIT is a dummy variable which is take the value 1 if farmer maintained a non-mandatory deposit in his account at the time of the credit origination and 0 otherwise

INVESTMENT represents the fixed deposit the farmer has. This is expected to be negatively related to collateral pledge. It takes the value one if yes and zero otherwise. How long the farmer has been in relationships with the financial institution is represented by LEDURATION. It is a continuous variable measured in years. The number of financial institutions the farmer deals with is a continuous VARIABLE represented by MULTYBANKS. It is expected that farmers who deal with more banks will be expected to provide collateral thank those who stick to one or few banks. Interest on the loan, type of the financial institution and the type of loan being granted are represented in the model by LINTEREST, TBANK and TLOAN respectively.

The farmers access to financial information through closeness to the officers of the financial institution and other income obtained by the farmer apart from income from maize are represented by FAINFO AND OINCOME respectively.

\section{Results and Discussion}

\subsection{Socioeconomic Characteristics of Farmers}

Table 1 show the distribution of maize farmers who were considered for the study in the study area. They borrowed for various reasons in the study. The results show that majority of the respondents are males (72\%) indicating that more males maize farmers are interested in taking loans than their female counters in the study area. Men are more expected to have more likelihood to reduce transaction cost than the females. The male dominance in maize production is also confirmed by [7]. The results also show that male household heads are dominant (85\%) across the two study regions. The male household-head dominance in this study is similar to the $80 \%$ male household-heads reported in a recent nation-wide survey by the [27], and $71.8 \%$ in rural forest reported in Ghana Living Standard Survey (GLSS6) in 2013. The large proportion of the male household heads is crucial in loan decision making since men in most African societies are the decision makers [61]. 
Table 1. Frequency Distribution of respondents according to Socioeconomic Characteristics and Sample Statistics

\begin{tabular}{|c|c|c|c|c|c|c|}
\hline \multicolumn{7}{|l|}{ REGIONS } \\
\hline \multirow{2}{*}{ Characteristic } & \multicolumn{2}{|c|}{ Ashanti Region } & \multicolumn{2}{|c|}{ Brong Ahafo Region } & \multicolumn{2}{|c|}{ Overall Total } \\
\hline & Number & $\%$ & Number & $\%$ & Number & $\%$ \\
\hline \multicolumn{7}{|l|}{ Gender } \\
\hline Male & 79 & 67.52 & 167 & 74.22 & 246 & 72 \\
\hline Female & 38 & 32.48 & 58 & 25.78 & 96 & 28 \\
\hline \multicolumn{7}{|l|}{ Marital Status } \\
\hline Single (divorce/separation) & 22 & 18.80 & 48 & 21.4 & 70 & 20.5 \\
\hline Married & 95 & 81.20 & 177 & 78.6 & 272 & 79.5 \\
\hline \multicolumn{7}{|l|}{ Household Head } \\
\hline Male & 96 & 82.05 & 195 & 86.6 & 291 & 85.08 \\
\hline Female & 21 & 17.95 & 30 & 13.4 & 51 & 14.92 \\
\hline \multicolumn{7}{|l|}{ Educational level of farmers } \\
\hline No education & 28 & 23.93 & 38 & 16.89 & 66 & 19.21 \\
\hline Primary/JSS/Middle school & 56 & 47.86 & 151 & 67.11 & 207 & 60.62 \\
\hline Secondary /diploma & 21 & 17.95 & 30 & 13.33 & 51 & 14.91 \\
\hline Tertiary & 12 & 10.26 & 6 & 2.67 & 18 & 5.26 \\
\hline \multicolumn{7}{|l|}{ Native } \\
\hline Yes & 85 & 72.65 & 156 & 69.33 & 241 & 70.46 \\
\hline no & 32 & 27.35 & 69 & 30.67 & 101 & 29.54 \\
\hline \multicolumn{7}{|l|}{ Age of farmer(years) } \\
\hline $18-44$ & 43 & 37.4 & 82 & 36.46 & 125 & 36.55 \\
\hline $45-60$ & 62 & 53.9 & 119 & 52.88 & 182 & 53.22 \\
\hline More than 60 & 11 & 9.7 & 24 & 10.66 & 35 & 10.23 \\
\hline \multicolumn{7}{|l|}{ Member of association } \\
\hline Yes & 26 & 22.22 & 57 & 25.33 & 83 & 24.67 \\
\hline No & 91 & 77.78 & 168 & 74.67 & 259 & 75.73 \\
\hline \multicolumn{7}{|l|}{ Extension services } \\
\hline Yes & 86 & 74 & 168 & 75 & 254 & 74 \\
\hline No & 31 & 26 & 57 & 25 & 88 & 26 \\
\hline
\end{tabular}

Source: Survey data.

The result further show that majority of the maize farmers (79.5\%) are married which implies that more consultative reasonable decisions are expected to be made by these farmers especially when it comes to the decision to take loans.

Education is very important when it comes to the credit market. For farmers to be able to apply and access credit, farmers need some level of education in order to understand the contract terms [49]. However the survey data suggests a high illiteracy rate among the maize farmers as about $80 \%$ had up to Primary/JSS/Middle school or no education at all. The low level of education in this study is similar to what was reported by the GLSS6 in 2013 in which those who had no education at all stood at $19.7 \%$, those who had up to middle school and JHS were $65.5 \%$ while those had Secondary/SSS/SHS and higher were $14.7 \%$.

Unlike cocoa farming in which farmers move from other communities, towns and regions to cultivate cocoa in Ashanti and more especially Brong Ahafo region, about $70 \%$ of the maize farmers were natives of their respective localities, districts and regions. The advantage is that the farmers know each other and are ready to offer a helping hand to the other. However that does not bring competition and new ways of producing maize.

The results show that majority of the maize farmers (75. \%) do not belong to any social group that helps them to arrange for group loans. Only 25\% were members of one form or the other. Respondents who belong to associations and are able to arrange for group loans are able to reduce their transaction cost in terms of expenses on collateral and the number of times they visit the bank.

The fact that about 90 percent of the farmers are below 60 years indicates that the maize production in the two regions and mainly done by energetic and agile farmers. The aged may not be interested in maize farming because of the tedious and the speed nature of the maize production which requires the application of fertilizers and watering. About $74 \%$ of the respondents had access to the services of extension officers for at least once a month. This is expected to boost up production since farmers will receive improved technical knowhow.

\subsection{Collateral Acceptance}

About $67 \%$ of respondents secured their loans with collaterals. This means that borrowers have to look for collaterals before their loans are approved.

Stated differently, financial institutions are always interested in protecting their funds and as such use all means to secure the loans before they are granted to the clients.

According to one of the managers in a rural bank at Dormaa, apart from securing the loans, taking the collateral put some sort of pressure on the borrowers to be committed thereby putting the money into good use in order not to lose their assets used as collateral. Productivity is thus improved when collaterals are taken, he added. 


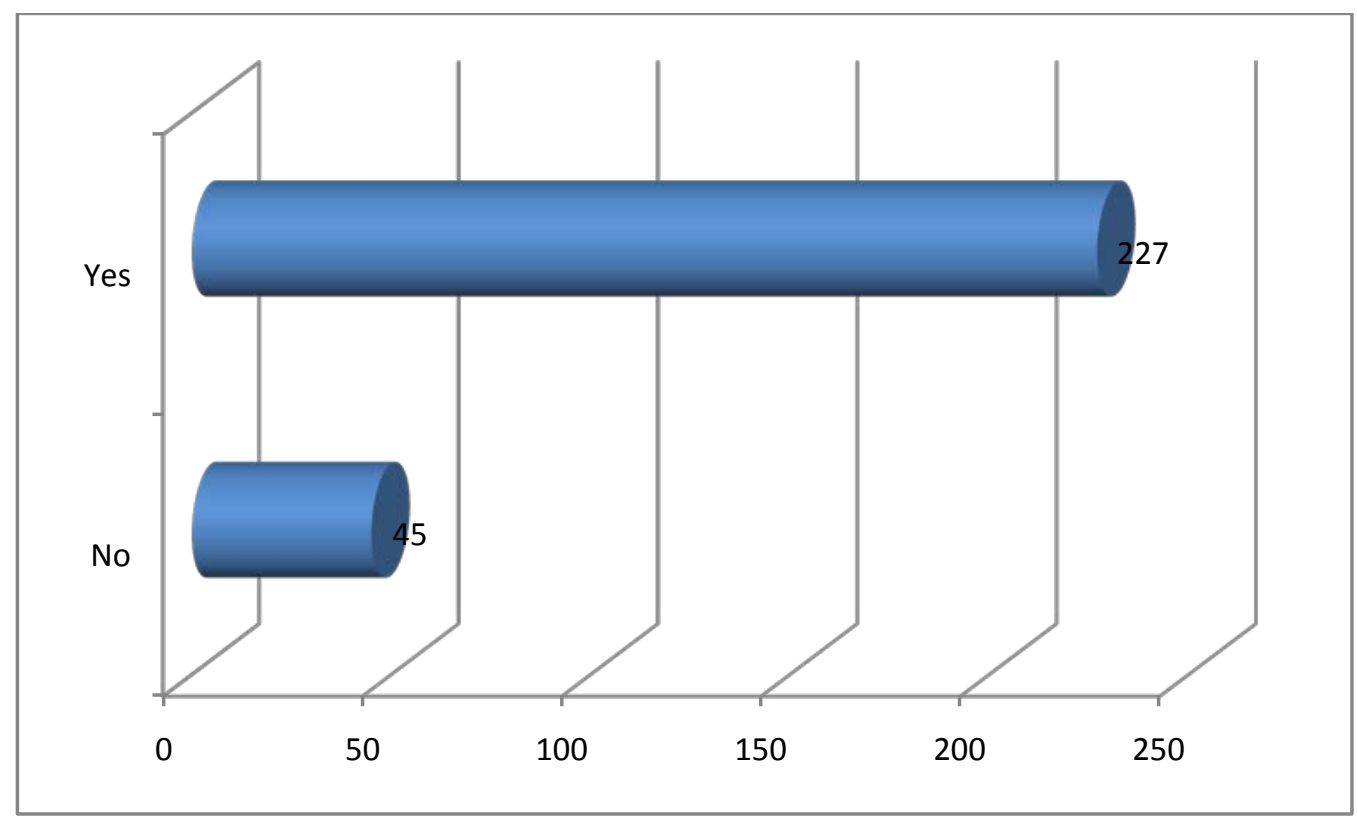

Figure 1. Acceptance of collateral (Source: From the field data)

Table 2. Collateral Accepted by various financial institutions

\begin{tabular}{|l|c|c|c|c|c|c|}
\hline \multirow{2}{*}{ Collateral Accepted } & \multicolumn{3}{|c|}{ Type of Financial Institution } & \multirow{2}{*}{ Total } & \multirow{2}{*}{ percentage } \\
\cline { 2 - 6 } & Rural Bank & Savings and Loans & Universal Bank & Corporative credit Society & \\
\hline Cash & 87 & 32 & 13 & 26 & 158 & 57.7 \\
Asset & 51 & 10 & 10 & 6 & 77 & 28.1 \\
Farm and Farmland & 1 & 0 & 1 & 1 & 3 & 1.1 \\
Guarantor & 22 & 9 & 2 & 3 & 36 & 13.1 \\
Total & 161 & 51 & 26 & 36 & 274 & \\
\hline
\end{tabular}

Source: From the field survey.

\subsection{Types of Collateral Accepted}

All the financial institutions took cash as collateral. Over $57 \%$ too cash collateral to secure the loan. This is because cash is liquid which can easily be used to pay back the loan. This also explains why farmers who have either savings or investments or both are given loan approval quickly and in full. In the case of the cash collateral, applicants are made to pay a certain percentage of the amount applied as security. In some cases customers who have susu accounts are made to save till they get $33 \%$ of the amount they want. In other cases, the client is made to pay the cash percentage upfront before the loan is approved for him. It is important to note that all cash collaterals are reversed back to the borrower after both the principal and interest on the loan has been paid fully. The customer can also ask the financial institution to use his collateral to set off an outstanding loan balance at certain point when the collateral is enough to clear the debt.

Ten out of the 26 representing 38\% applicants who took loans from the universal banks were made to secure their loans with Assets like buildings, cars and other fixed assets. No wonder more farmers are interested in dealing with Rural Banks who are interested in less assets but more cash collateral

Only few financial institutions accepted Farm lands as collateral because of the difficulties in selling them to get back the money in case of default. About 13\% mostly in the rural banks also accepted guarantors as collateral to secure the loan. This normally happened when the amount involved were too small sometimes below GHc 1000. But in all cases, guarantors are used in addition to other forms of collateral

\subsection{Relationship Lending and Collateral Requirements}

The results of the logit regression model on factors that influence the financial institutions to demand collateral from the maize farmers or not are presented in Table 3.

The regression gave an $\mathrm{R}$ - squared value of 0.43 which implies that all the explanatory variables included in the model are able to explain about 43 percent of the variations in the collateral pledge by the maize farmers when the relationship variables are included in the model. It can be observed that the coefficient of investment is negative and statistically significant at $1 \%$. This means that if the farmer increases in the farmer's investment level by one Ghana cedi, the farmer is about $4 \%$ likely to have reduction in the collateral requirements from the financial institution. This is because the banks see such a farmer as less risky since that investment can be used to secure the loan. This finding support that of [13] and [21]. 
Table 3. The Logit regression results of the effects of relationships on Collateral pledge

\begin{tabular}{|c|c|c|c|c|}
\hline Independent Variables & Coefficients & Std Err & P-values & Marg Effect \\
\hline constant & $13.7793 * *$ & 4.9677 & 0.006 & 0.0394 \\
\hline Age of farmer & -0.0286 & 0.0313 & 0.361 & -0.0009 \\
\hline \multicolumn{5}{|l|}{ Loan characteristics } \\
\hline Outstanding Loan Balance & $0 . .0028 * * *$ & 0.0008 & 0.001 & 0.0000 \\
\hline Interest on Loan & $-0.1112^{* * *}$ & 0.0692 & 0.0108 & -0.0035 \\
\hline Loan Amount & $0.0004 *$ & & 0.095 & 0.0001 \\
\hline Loan Duration & -0.853 & 0.2792 & 0.002 & -0.027 \\
\hline \multicolumn{5}{|l|}{ Relationship variables } \\
\hline farmers with Deposit & $-0.0133^{* *}$ & 0.6469 & 0.048 & -0.0341 \\
\hline Farmers Access To Financial Information & $-1.2965^{*}$ & 0.6761 & 0.055 & -0.0411 \\
\hline Duration of Account Operation & $1.7848 * * *$ & 0.629 & 0.005 & 0.0947 \\
\hline Multiple Banking Relationships & 1.001 & 0.7374 & 0.174 & 0.0291 \\
\hline Previous Loan Repayment Behavior & $-1.7172 * *$ & 0.8008 & 0.032 & -0.0885 \\
\hline farmers with Investments & $-1.1801^{* * *}$ & 0.6601 & 0.007 & -0.0349 \\
\hline \multicolumn{5}{|l|}{ Household and other characteristics } \\
\hline other income & $0.0268 *$ & 0.0313 & 0.056 & -0.0085 \\
\hline competition faced by farmers & 0.5483 & 0.6205 & 0.377 & 0.0201 \\
\hline Dependency Ratio & 0.0463 & 0.0244 & 0.058 & 0.0014 \\
\hline Farmers size & $-0.0332 *$ & 0.018 & 0.066 & -0.00105 \\
\hline Number of obs= & 308 & & & \\
\hline $\operatorname{LR} \operatorname{Chi}^{2}(14)=$ & 82.88 & & & \\
\hline prob $>\mathrm{chi}^{2}=$ & 0.0013 & & & \\
\hline PseudonR $R^{2}=$ & 0.4324 & & & \\
\hline
\end{tabular}

Source: field data Figures in parenthesis stand for standard error (* Significant at 10\%; ** significant at 5\%; *** significant at $1 \%$.

Apart from the investment, farmers who have deposits in their account at the time of loan processing can also influence the collateral the use to secure their loans. The coefficient of farmers with deposit in their accounts is negative and significant at $5 \%$. Thus a cedi increase in savings deposit decreases the likelihood pledging collateral by $3 \%$. This is because lenders used borrowers' savings as a proxy for account turnover and measure of ability to pay on time.

The duration of account operations with the financial institution is positively related to the collateral pledging by the farmer. This is contrary to expectations and the findings of [19] who saw negative relationship between collateral pledging and duration of account operations, but confirms the findings of [13] who found that the probability of not pledging collateral decreases with the length of bank-customer relationship. An increase in the number of years the farmer deals with the bank increases the probability of the bank demanding collateral by $9.4 \% \%$. This is because as the farmer operates the account for a long time, the desire to switch to other banks reduces, their banks thus capitalize on it to increase collateral and sometimes the interest charged [53].

Multiple Banking Relationships has direct relationships with the collateral demand. In our case banks are willing to reduce collateral demand for farmers who solely deal with one bank. From the results, coefficient of Multiple Banking Relationships, is positive meaning that as the farmer decides to borrow from more banks, the collateral demand increases and vice versa. Thus an increase in the number of banks the farmers borrows from by one, has the potential to increase the collateral pledging by $3 \%$. This because multiple borrowers are seen to be risky to be dealt with since they expose the bank to the risk of diversion and may not be trustworthy [39,52,62].

The coefficient of previous loan repayment behavior is negative and significant at 5\%. This confirms the findings of [49] which stated that good repayment reduces collateral requirements. Farmers who pay their loans on time are seen to be reliable and less risky and thus collateral demands come down to encourage them to take more loans. Farmers who are able to pay their loans when it false due are likely to reduce the collateral pledge by 9 percent.

It can be seen from Table 3 that farmers who are able to access information from the banks as a results of their close relationships with officers are able to reduce the collateral pledge. The coefficient is negative meaning the more the farmers get information the lower the collateral pledge. A one percent improvement in the farmers access to information in the bank, leads to a reduction in collateral requirements by $4 \%$. This is consistent with the findings of Udell (2008).

The coefficient of outstanding loan is positive and statistically significant at $1 \%$. That means those who have huge loan outstanding are made to secure their loans with more collateral since they are seen to be risky as was opined by Peterson and Rajan (2001).

The interest on loan is inversely related to the collateral pledge since even the high interest itself is seen as 
collateral .The interest variable is significant at $1 \%$. Thus farmers who pay higher interest are made to secure their loans with relatively lower collateral.

In the same way the size of the loan varies directly as the collateral pledge. The higher the size,the higher the collateral. Thus the size of the loan is significant at $10 \%$. This also agrees with [13].

The size of the farm is a measure of farmers' ability to pay. As it increases the collateral pledge comes down as the farmer is seen to have the ability to pay and less risky.

Farmers with other sources of income too are seen to be less risky thus reducing the collateral for them is in order as can be seen in the Table 3 As the size other income increases the collateral demands come down as suggested by Peterson and Rajan (2001).

Those with high dependency ratio are also seen to be risky and thus are made to secure the loan s as the size the loan size increases.

\section{Conclusion and Policy Implication}

The results obtained in this study, based on the logit model, revealed that access to the requisite financial information has the potential to reduce the collateral pledge by farmers

Similarly, farmers who are able to pay their loans when the repayment date falls due are more likely to be exempted or get reduction in collateral demanded by the banks when accessing loans. In the same way farmers who have investments in the form of fixed deposits also are able to get reduction in collateral demanded by the banks. However it was found that multiple banking relationships with banks have the potential to increase the collateral demanded by the banks. Furthermore the study found that dealing with a financial institution for a long time also has the potential to increase the collaterals demanded by the bank Any strategy aimed at encouraging farmers to save and invest more with their banks is recommended as a policy option for reducing collateral pledge by the farmers when accessing loans. However multiple banking relationships should be discouraged among farmers so as to improve their relationship with their banks and reduce the transaction cost on loans.

\section{References}

[1] Akhavein, Jalal., Goldberg, L. G. and White, L. J. (2004). "Small Banks, Small Business and Relationships: An Empirical Study of Lending to Small Farms”, Journal of Financial Services Research, 26, 245-261.

[2] Amemiya, T. (1981). "Qualitative Response Model: A Survey". Journal of Economic literature 19: 1483-1536.

[3] Angelini, P., Di Salvo, R. and Ferri, G. (1998): “Availability and Cost of Credit for Small Businesses: Customer relationships and Credit Cooperatives”, Journal of Banking and Finance 22: 925-954.

[4] Arano, K.G. (2007). Determinants of loan interest rates: Evidence from the survey of small business finances (SSBF).

[5] Avery, R. B. and Samolyk, K. A. (2004). Bank Consolidation and Small Business Lending: The Role of Community Banks. Journal of Financial Services Research, 25(2/3), 291-325.

[6] Awoke, M.U. (2004). Factors affecting loan Acquisition and Repayment pattern of small holder farmers in Ika North East of Delta State Nigeria, J. Sustainable Trop. Agric. Res. 9:61-64.
[7] Awunyo-Vitor, D. (2012). Determinants Of Loan Reyament Default Among Farmers In Ghana . Journal of Development And Agricultural Economics, Vol 4 pp 339-345.

[8] Baas, T. and Schrooten, M. (2006). Relationship banking and SMEs a theoretical analysis. Small business Economics vol 10 pp 127-137.

[9] Bank of Ghana (2010). Bank of Ghana Annual report, 2010.

[10] Bartlett, J.E, Kotrlik, I.J.W. and Higgins, C.C. (2001). "Organizational Research: Determining the Appropriate Sample Size in Survey Research”. Information Technology, Learning and Performance Journal 19(1) 43-50.

[11] Bee, K. F. (2007). Rural Financial Market in Tanzania: An analysis of access to financial services in Babati District, Manyara Regio. PhD Thesis, University of South Africa.

[12] Berger, A. N. and Black, L. K. (2013). Bank size, lending technologies, and small business finance. Journal of Banking \& Finance, 35(3), 724.

[13] Berger, A. N. and Udell, G. F. (1995). "Relationship lending and lines of credit in small form Finance". The Journal of business, Vol. 68, No.3 (Jul., 1995), pp. 351-381. Published by the University of Chicago Press.

[14] Berger, A. N., Leora F. K. and Udell, G F. (2001). "The Ability of Banks to Lend to Informationally Opaque Small Business", Journal of Banking \& Finance, 25, 2127-2167.

[15] Berger, A.N., Udell, G.F. (2006), "A more complete conceptual framework for SME finance", Journal of Banking and Finance, Vol. 30, 2945-2966

[16] Berlin, M. and Mester, L. J. (1998). "On the Profitability and Cost of Relationship Lending”, Journal of Banking \& Finance, 22, 873-897.

[17] Blazy, R. and Weill, L. (2006). "Why Do Banks Ask for Collateral?”, University of Strasbourg - LaRGE Research Center (Laboratoire de Recherche en Gestion et Economie).

[18] Boateng S.S. (2009). Factors Militating Against the Academic Growth of Females in the Dangme-West District; A Dissertation Submitted To the Institute of Education of the Faculty of Education University of Cape Coast,in Partial Fulfillment of the Requirements for the Award of Master of Education Degree in Educational Management.

[19] Boot, A. and Thakor, A.V. (1994). Moral hazard and secured lending in an infinitely repeated credit market game, International Economic Review, 35, 899-920.

[20] Chakravarty, Sugato and Yilmazer, Tansel. (2009). "A Multistage Model of Loans and the Role of Relationships." Financial Management, 38 (4), pp. 781-816.

[21] Cole, R. A.(1998.). "The Importance of Relationships to the Availability of Credit.” Journal of Banking and Finance, 22, pp. 959-977.

[22] D’Auria,C., Fogia, A. and Reeddtz, P.M. (1999) bank interest rate and credit relationships in Italy . Journal of banking and finance vol 23, 10067-10093.

[23] Degryse, Hans and Cayseele Patrick Van.( 2000). "Relationship Lending within a Bank-Based System: Evidence from European Small Business Data.” Journal of Financial Intermediation, 9(1), pp. 90-109.

[24] Diamond, D. (1991). Monitoring and reputation: the choice between bank loans and directly placed debt, Journal of Political Economy, 99, 689-721.

[25] Dong, F., Lu, J. and Feathersone, A. (2010). Effects of Credit Constraint on Productivity and Rural Household Income in China Selected Paper prepared for presentation at the Agricultural \& Applied Economics Association 2010 AAEA, CAES, \& W AEA Joint Annual Meeting, Denver, Colorado, July 25-27.

[26] Folawewo O. A. and Tennant D. (2008). Determinants of interest spread in Sub-Sarahan African countries: a dynamic panel analysis. Unpublished.

[27] Food and Agriculture Organisation (FAO) (2012c). FAO Database. FAO, available at http://faostat.fao.org/site/617/default.aspx\#ancor.

[28] Ghana Statistical Service (2005a). Socioeconomic and Demographic Trends in Ghana. Vol 1, Population Data Analysis Report.

[29] Ghana Statistical Service (2005b). 2000 population and housing census: Brong Ahafo Region: Analysis of districts data and implication for planning.

[30] Ghana Statistical Service (GSS) (2014). 2010 population and housing census Summary Statistics, Ghana Statistical Services, Accra, Ghana. 
[31] Graham, D. H., Schreiner, M. and Leon, J. 1993. Transaction Costs Issues in Rural Finance: A Review of the Arguments and Recent Evidence in Asia. Transaction Costs of Farm Credit in Asia, Report of APO Seminar, $30^{\text {th }}$ November $10^{\text {th }}$ December, Tokyo, Japan. Pp.82.

[32] Gujarati DN (1998). Basic Econometrics. 2nd Edition McGrawHill Book Company. New York. Pp: 580-601.

[33] Harvey, J.H. (1995) The odyssey of the heart. The search for closeness, intimacy and love . New York freeman.

[34] Hasan, Kabir M. (2002). "The Microfinance Revolution and the Grameen Bank Experience in Bangladesh.” Financial Markets, Institutions and Instruments, 11 (3), pp. 205-265.

[35] Hoff, K. and Stieglitz, J.E., 1990. Introduction: Imperfect information and rural credit markets: Puzzles and policy perspectives. The world bank economic review, 4(3), pp.235-250.

[36] Hoffman, S.D. and Duncan, G.J. (1988). Multinomial and conditional logit discrete-choice models in demography. Population Association of America, 25(3), 415-427.

[37] Hosmer, D.W. and Lemeshew, S. (1989). Applied Logistic Regression. A Wiley-Inter science Publication, New York.

[38] Hosseini, S.S., Khaledi, M., Ghorbani. M. and Brewin,D. G. (2012). An Analysis of Transaction costs of Borrowing Credit in Rural Iran, Agric Science Tech (2012) Vol. 4.

[39] Husted, B.W. and Folger, R. (2004). Fairness and transaction costs: The contribution of organizational justice theory to an integrative model of economic organization. Organization science, Vil. 15, No. 6 (Nov. Dec., 2004), pp. 719-729.

[40] Jimenez, Gabriel, Vicente Salasa, and Jesus Saurina, (2006). "Determinants of Collateral”, Journal of Financial Economics, 81, 255-281.

[41] Khaledi, M. (2005). Assessing the Effects of Transaction Costs on Agricultural Producers in Iran, Case Study: Rice Producers. A Thesis Submitted in Partial Fulfillment for the Degree of Ph.D. in Agricultural Economics, Agricultural Faculty, Department of Agricultural Economics, Tehran University. (in Persian).

[42] Lehmann, E. and Neuberger, D. (2001). 'Do lending relationships matter? Evidence from bank survey data in Germany', Journal of Economic Behavior and Organization 45: 339.

[43] Levine, R. (1997). "Financial development and economic growth: Views and Agenda”. Journal of economic literature, June 1997 35,2j ABI/INFORM GLOBAL Pg. 688.

[44] Lukas N. Abatania, Atakelty Hailu and Amin W. Mugera. (2012), Analysis of Farm House hold Technical Efficiency in Northern Ghana using Bootstrap DEA, Paper presented at the $56^{\text {th }}$ Annual Conference of the Australian Agricultural and Resource Economics Society.

[45] Mayer, R. C., Davies, J. A. and Schoorman, F. D. (1995). "An Integrative Model of Organisational Trust”, Academy of Management Review, 20, 709-734.

[46] Ministry of Food and Agriculture (2008). Agriculture in Ghana Facts and Figures, 2009 MoFA Ghana Publication.

[47] Ministry of Food and Agriculture (2012). Agriculture in Ghana Facts and Figures, 2009 MoFA Ghana Publication.

[48] Ministry of Food and Agriculture (2013). Agriculture in Ghana Facts and Figures, 2009 MoFA.
[49] Nalukenge, I.K. (2003). "Impact of Lending Relationships On Transaction Costs Incurred by Financial Intermediaries”: A dissertation presented in partial fulfilment of the Requirements for The Degree Doctor of Philosophy in the Graduate School of The Ohio State University 2003.

[50] Nwaru, J.C. (2004). "Rural credit market and resource use in arable crop production in imo state of Nigeria” .PhD Dissertation, Michael Okpara, University of Agriculture, Umudike, Nigeria.

[51] Okurut, N., Schoombee, A. and Van der Berg, S. (2004). Credit Demand and Credit Rationing in the Informal Financial Sector in Uganda. African Development and Poverty Reduction: The Macro-Micro Linkage. Forum Paper, 13-15, South Africa.

[52] Petersen, M.A and Rajan, R.G. (1994). "The benefits of lending relationships: Evidence from small Business Data”. The journal of Finance. Vol. XLIX, No. 1 March 1994.

[53] Petersen, M.A and Rajan, R.G. (2001). "Does distance still matter?” The information revolution in small business lending.

[54] Petersen, Mitchell A., and Raghuram G. Rajan, (1995). "The Effect of Credit Market Competition on Lending Relationship", Quarterly Journal of Economics, May, 407-443.

[55] Sharpe, S. (1990). Asymmetric information, bank lending and implicit contracts: astylized model of customer relationships, Journal of Finance, 45, 1069-108.

[56] Ssewanyana, J and Busler, M. (2007). Adoption and usage of ICT in developing countries: Case of Ugandan firms. International Journal of Education and Development using information and Communication Technology (IJEDICT), 2007, Vol.3, Issue 3, pp.49-59.

[57] Steel, W. F. and Andah, D. O. (2003). Rural and Micro Finance Regulation in Ghana: Implications for Development and Performance of the industry; Africa Region Working Paper Series No. 49; World Bank.

[58] Steijvers, T., Voordeckers, W. and Vanhoof, K. (2010). "Collateral, Relationship Lending and Family Firms", Small Business Economics, 34, 243-259.

[59] Sugato, C. and Abu, S. (2010). Relationship lending in micro credit: Evidence from Bangladesh.

[60] Swinnen, J.F.M. and Gow, H.R. (1999). Agricultural credit problems and policies during the Transition to a Market Economy in Central and Easten Europe Food Policy 24(1999). 21-24.

[61] Turkson, P. K., and Naandam, J. (2006). Constraints to ruminant production in East Mamprusi Districts of Ghana. Ghana Journal of Agriculture Science, 39, 155-164.

[62] Udell, G. F. "What's in A Relationship? The Case of Commercial Lending.” Business Horizons 51, (2008): 93-103.

[63] Udoh, E.J., Kormawa, P.M. (2009). Determinants for cassava production expansion in the semi-arid zone of West Africa. Environmental, Development and Sustainability, 11(2), 345-357.

[64] Voordeckers, W. and Steijvers, T.(2006), "Business Collateral and Personal Commitments in SME Lending” Journal of Banking \& Finance, 30, 3067-3086.

[65] World Bank (1975). Agricultural credit sector policy Review. World Bank, Washington DC. 